factors are nearly equal, and will be tedious when $m$ is largei.e. when the factors are very unequal; and most tedious of all when $\mathrm{N}$ is a prime, when the number of steps $(m)$ required will be $m=\frac{1}{2}(\mathrm{~A}-\mathrm{r})$ or $\frac{1}{2}(\mathrm{~A}-2)$, according as $\mathrm{A}$ is odd or even, which is obviously a very high number for high numbers $\mathrm{N}$.

A different "shortening process" is proposed (by Mr. Hudson) on p. 5I I of NATURE, which amounts to this. When the two numbers $(\mathrm{A}+r)$ and $\left\{(\mathrm{A}+r)^{2}-\mathrm{N}\right\}$, or, again, when the two numbers $(\mathrm{B}-r)$ and $\left\{(\mathrm{B}-r)^{2}+\mathrm{N}\right\}$, have a common measure, that common measure is (as is easily seen) one of the factors of $\mathrm{N}$; and, if it can be recognized, at once solves the question. Unfortunately, this will be in general of little practical help, except when one of the four numbers operated on is quite small, as otherwise it is not easy to recognize (quickly) the fact of there being a common measure.

Chatham, March 30.
Allan Cunningham, Lieut.-Col. R.E.

\section{THE GEOGRAPHICAL RESULTS OF} MR. STANLEY'S EXPEDITION.

$\mathrm{I}^{\mathrm{T}}$ is evident from Mr. Stanley's stirring letters, which during the past week have cast all other topics into the shade, that pioneering in Africa is not yet at an end, and that that strange continent has not yielded up its last wonder to knowledge. The letters are suggestive of many things. Much could be said in admiration of the heroism and generalship displayed; much as to the difficulties encountered and the sufferings and losses sustained; much as to the route selected, and much as to the conduct of the party left at Yambuya. But in the first place this is hardly the proper place to speak of these aspects of the expedition, and in the second place it is only fair to wait for the full narrative before venturing upon criticism. No one who knows Mr. Stanley had ever any doubt of his success, or could ever believe that he would allow himself to die before accomplishing his work. It is clear that to anyone who has it in him to do heroic deeds there is still ample scope in Africa.

What we have to do with here are the geographical results of Mr. Stanley's expedition. And here again we are met by the fact that the expedition was not properly one of exploration; at least, this feature was only secondary to the main object of the expedition, the "relief" of Emin Pasha, himself a contributor to science of high rank. Again, even the communication to the Royal Geographical Society can only be regarded as a few preliminary notes on the additions made to our knowledge of one of the most interesting regions in Africa; for the full results, which cannot but be of high value and interest, we must wait for Mr. Stanley's full narrative, which will doubtless include the results obtained by the scientific members of his staff. As the region through which the expedition passed was previously entirely unknown, fresh additions to our knowledge were inevitable. As to the character of this region, it is evident that, so far as time and danger and difficulties are concerned, no worse route could have been chosen. It is now well known that the Committee and Mr. Stanley yielded to influences which ought not to have weighe 1 with them, in view of the main purpose of the Expedition, and that Mr. Stanley's own preference would have been for the East Coast route. Had this route been selected, no doubt there might have been difficulties with the Masai; forests would have had to be traversed, deserts crossed, and swamps trudged through; but all these obstacles combined would have been trifling compared with the terrors of the Aruwimi jungles, and their suspicious and ferocious inhabitants. However, Science has nothing to complain of: the gain has been all on her side.

Mr. Stanley has passed through one of the great blanks of Central Africa. Much of it was untrodden even by the deadly foot of the Arab slaver. Dr. Junker just touched its northern fringe; he had reached the Nepoko River apparently in its upper course; but from about $3^{\circ} \mathrm{N}$. to about $4^{\circ} \mathrm{S}$., and between the Upper Congo on the west and the lakes on the east, we have virtually a great blank. It is the northern part of this blank which Mr. Stanley has enabled us to fill in; and when he comes home he will probably be able to tell us more than we yet know. In the particular region with which he was concerned we wanted to know the course of the Aruwimi and its tributaries; the character of the country and people through which it passes; the position and extent of the lake (Muta Nzigé) to the south of Albert Nyanza, and its relation either to the Nile or the Congo. Some of these problems Mr. Stanley has solved; others, no doubt, he will have solved by this time.

One thing is clear, the Expedition passed through the northern section of what is probably the greatest forest region in Africa, extending from about $3^{\circ} \mathrm{N}$. to $4^{\circ} \mathrm{S}$., and from about $23^{\circ}$ to $30^{\circ} \mathrm{E}$. Junker met with it on the Nepoko, and Livingstone in his weary journey from Tanganyika to Nyangwe. It was dense enough in both cases, but nothing apparently compared with what Stanley found it to be on the Aruwimi. The route, he tells us, was covered with creepers varying from $\frac{1}{8}$ of an inch to 15 inches in thickness, swinging across the path in bowlines or loops, sometimes matted and twisted together; also of a low, dense brush occupying the sites of old clearings which had to be carved through before a passage was possible. Where the clearings had been abandoned for some years was found a young forest, the spaces between the trees choked with climbing plants and vegetable creepers. This had to be tunnelled through before an inch of progress could be made. Mr. Stanley's description of the character and extent of this forest in his letter to Mr. Bruce is quite worth quoting :-

"Take a thick Scottish copse, dripping with rain; imagine this copse to be a mere undergrowth, nourished under the impenetrable shade of ancient trees, ranging from Ioo to 180 feet high; briars and thorns abundant; lazy creeks meandering through the depths of the jungle, and sometimes a deep affluent of a great river. Imagine this forest and jungle in all stages of decay and growthold trees falling, leaning perilously over, fallen prostrate ; ants and insects of all kinds, sizes, and colours murmuring around, monkeys and chimpanzees above, queer noises of birds and animals, crashes in the jungle as troops of elephants rush away; dwarfs with poisoned arrows securely hidden behind some buttress or in some dark recess ; strong brown-bodied aborigines with terribly sharp spears, standing poised, still as dead stumps ; rain pattering down on you every other day in the year; an impure atmosphere, with its dread consequences, fever and dysentery; gloom throughout the day, and darkness almost palpable throughout the night; and then, if you will imagine such a forest extending the entire distance from Plymouth to Peterhead, you will have a fair idea of some of the inconveniences endured by us from June 28 to December 5, I887, and from June I, I 888 , to the present date, to continue again from the present date till about December IO, I888, when I hope then to say a last farewell to the Congo forest."

Here, then, we have a forest region very different from any other forest region of any extent in Africa. Prof. Drummond, in his recent book on Africa, describes very clearly the typical forest of Central and Southern Africa ; the trees mostly standing apart, with very little brushwood, and in many places no difficulty in penetrating it even with a Cape cart. The rank exuberance of the Aruwimi forest can hardly be due to the abundance of water in the shape of lakes and rivers; for away south in the region recently traversed by Mr. Arnot, the region described by Livingstone as a great sponge, where the feeders of the Zambesi, the Congo, and other great rivers, take their rise, and on the east of which lie Tanganyika and Bangweolo 
lakes, we find, so far as we know at present, no such dense bush, though the grass is high, and rank, and thick enough. Mr. Stanley attempts to account for the abundance of water and the thickness of the forest by the moisture carried over the continent from the wide Atlantic, by the winds which blow landwards through a great part of the year. But as a comparatively cold current sweeps along the coast from the south, these winds may be colder than the surface of the land over which they pass, and so may decline to part with their moisture. But this is a point for careful investigation; and it may after all be found that the rain of the rainiest region of Africa comes not from the Atlantic but the Indian Ocean, with its moisture-laden monsoons; and so we should have here a phenomenon analogous to that which prevails in the South American continent, the forests of which resemble in many features those of the region through which Mr. Stanley has passed.

The forest itself is not more interesting than its human denizens. Mr. Stanley mentions the names of many tribes living along the river, and judging from their names they seem all more or less of Bantu affinities. But we are here

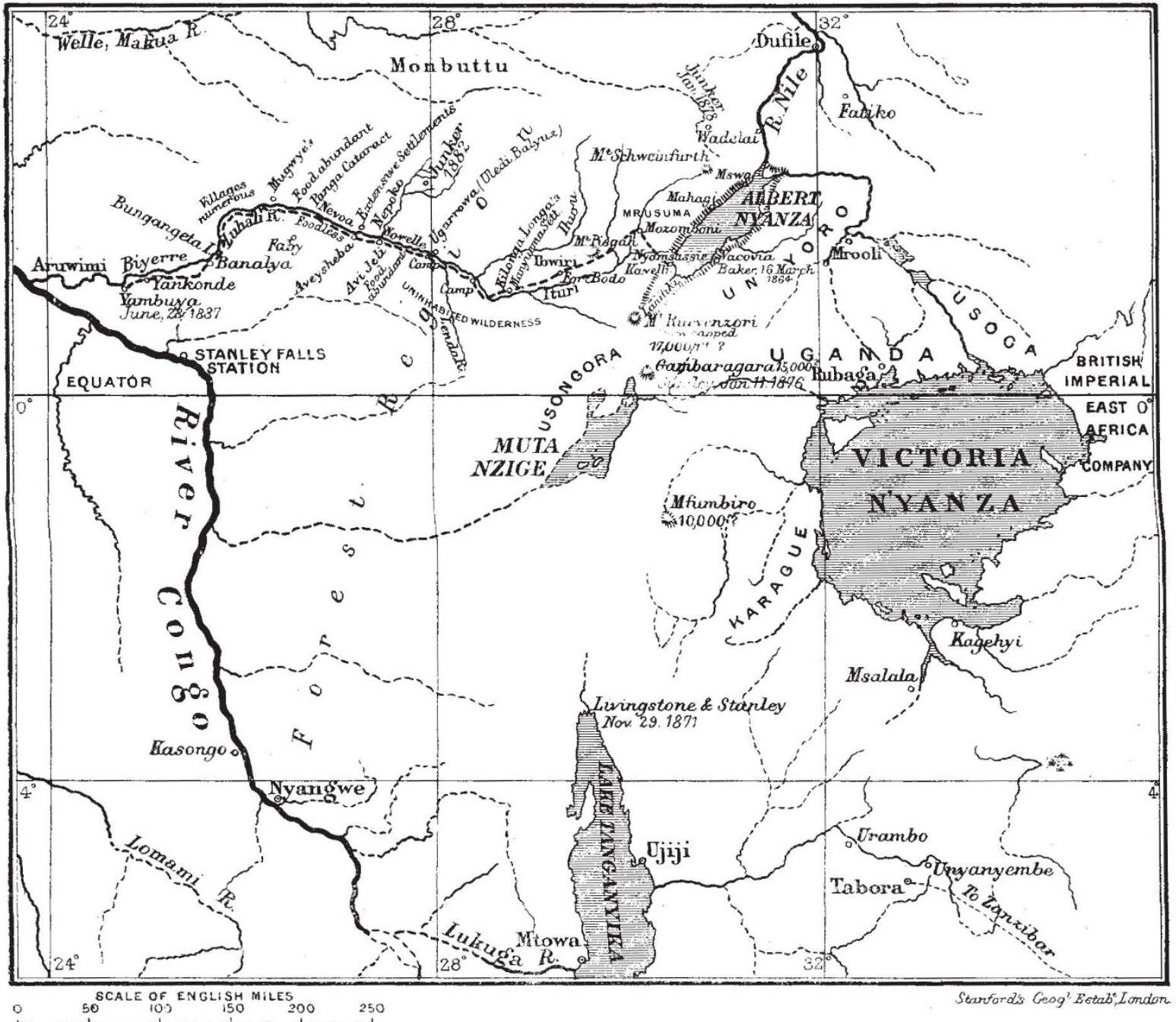

verging on the limits of the Negro peoples, so that when we obtain full information it may be found that the Aruwimi tribes are much mixed. But it will be of the greatest interest to ascertain what has been the effect upon these peoples of their sad and depressing and eversaturated surroundings; and to compare the results with what we find to be the case in more open country with people of the same type. That there have been changes in the population of the region is evident from the great heaps of oyster-shells met with by $\mathrm{Mr}$. Stanley, some of them covered by several feet of earth.
One important piece of information Mr. Stanley gives us concerning these forest tribes. Nejambi Rapids, about 250 miles above the junction of the Aruwimi and the Congo, marks the division between two different kinds of architecture and language. Below, the cone huts are to be found; above the rapids we bave villages, long and straight, of detached square huts surrounded by tall logs, which form separate courts, and add materially to the strength of the village. Many precautions are adopted against attacks by poisoned arrows. Mr. Stanley lost several men by these arrows, and Lieutenant 
Stairs had a narrow escape. It was afterwards found that the poison is manufactured from the dried bodies of red ants or pismires ground into powder, cooked in palmoil, and smeared over the wooden points of the arrows. As might have been expected, the forest is haunted by myriads of insects of every variety, and it is to be hoped that a harvest of these have been gathered for the delight of the entomologists at home.

Mr. Stanley's description of the daily course of things in the forest region is worth quoting :-

"The mornings generally were stern and sombre, the sky covered with lowering and heavy clouds, at other times thick mist buried everything, clearing off about 9 a.m., sometimes not till I I a.m. Nothing stirs then ; insect life is still asleep, the forest is still as death, the dark river, darkened by lofty walls of thick forest and vegetation, is silent as a grave; our heart-throbs seem almost clamorous, and our inmost thoughts loud. If no rain follows this darkness, the sun appears from behind the cloudy masses, the mist disappears, life wakens up before its brilliancy. Butterflies scurry through the air, a solitary ibis croaks an alarm, a diver flies across the stream, the forest is full of a strange murmur, and somewhere up river booms the alarum drum. The quicksighted natives have seen us, voices vociferate challenges, there is a flash of spears, and hostile passions are aroused."

As to the river itself, the Aruwimi, or Ituri (it has several other names), is, with its windings, about 800 miles long, from its mouth in the Congo to its source almost on the edge of Albert Nyanza, though the course in a direct line is probably not more than 400 miles. The banks of the river, covered with forest from the Congo to the Nepoko (which is, after all, only a branch of the main river), are uniformly low, here and there rising to about 40 feet. Above the Nepoko, hills begin to crop up more frequently, palms are more numerous, and the woods show the tall, white-stemmed trees so characteristic of the slopes of the Lower Congo. Wbile there are rapids at several places above Yambuya, above the Nepoko navigation becomes much more difficult, and rapids more frequent, while two considerable falls are met with. The land rises steadily until about 400 miles above Yambuya, the river is contracted into a rushing stream about Ioo yards wide, banked by the steep walls of a cañon, the slopes and summits of which are clothed with wood. Whatever changes the face of the land may show, the forest covers peak, hill, ridge, valley, plain,- everywhere it is continuous, never broken, except at such clearings as man has made. Mr. Stanley very graphically compares the country traversed by his expedition to the long glacis of a fort rising from the Congo to a height of 5000 to 6000 feet ; down the slope flows the Aruwimi, one of whose feeders runs almost within sight of Albert Nyanza, to which there is a sudden drop of 2900 feet.

"The main Ituri, at the distance of 680 miles from its mouth, is 125 yards wide, 9 feet deep, and has a current of 3 knots. It appears to run parallel with the Nyanza. Near that group of cones and hills, affectionately named Mount Schweinfurth, Mount Junker, and Mount Speke, I would place its highest source. Draw three or four respectable streams draining into it from the crest of plateau overlooking the Albert Nyanza, and two or three respectable streams flowing into it from north-westerly let the main stream flow south-west to near N. lat. $I^{\circ}$; give it a bow-like form $\mathrm{N}$. lat. $\mathrm{I}^{\circ}$ to $\mathrm{N}$. lat. $\mathrm{I}^{\circ} 5 \mathrm{O}^{\prime}$; then let it flow with curves and bends down to $\mathrm{N}$. lat. $\mathrm{I}^{\circ} \mathrm{I} 7^{\prime}$ near Yambuya, and you have a sketch of the course of the Aruwimi or Ituri from the highest source down to its mouth, and the length of this Congo tributary will be 800 miles."

Here, then, we have remarkable hydrographical conditions. Only a few minutes' walk separates the feeders of the Congo and the Nile in this part cular region. On the other side, again, are found streams flowing into the south of Victoria Nyanza rising close to others which run into Lake Tanganyika, which again, through the Lukuga, is believed to be a feeder of the Congo. Still further south are found the main Congo stream and its feeders rising in such close proximity to the source of the Zambesi that it is difficult to discrimate between the one and the other. Mr. Stanley's own lake, the Muta Nzige, of which he heard again when in the neighbourhood, very probably belongs not to the Nile but the Congo. All this is full of interest, and geographers will look with impatience for the publication of Mr. Stanley's detailed narrative.

Another fact of great interest Mr. Stanley refers tothe existence of a snowy mountain which may rival Kilimanjaro (19,000 feet), in the neighbourhood of Mount Gambaragara, or Gordon Bennett, between Albert Nyanza and Muta Nzige. This may be Mount Gordon Bennett itself, but Mr. Stanley does not think so, and he is supported by the few data which he furnishes. It would be quite in accordance with what we find in other parts of the world that a group of high peaks should be found together.

One other point of geographical interest is Mr. Stanley's observation that the Albert Nyanza is rapidly decreasing in size. A century or perhaps more ago, the lake must have been twelve or fifteen miles longer, and considerably broader opposite Mbakovia, than it is now. With the wearing away of the reefs obstructing the Nile below Wadelai, the lake has rapidly receded, and is still doing so, to the astonishment of Emin Pasha, who first saw Lake Albert seven or eight years ago. It is to be hoped that $\mathrm{Mr}$. Stanley will find time further to investigate this subject, as well as to explore the country between the Albert Nyanza and Muta Nzige, settle the position and outline of the latter, and ascertain precisely to what river system it belong.

The abruptness with which the forest comes to an end and the rich grass lands begin, about eighty miles from Albert Xyanza, is another point deserving special attention, and can only be explained when we have accurate observations of the rainfall and other conditions that go to form climate.

Such are some of the more important geographical results of Mr. Stanley's expedition, so far as we can gather from his preliminary letters; others may be derived from the map which accompanies his papers. More will no doubt follow. It is to be hoped that the rumour of Emin's return is not true, or at least that if he is coming to Europe he has left his province in efficient hands. In the interests of science as well as of humanity, it is important that the province which Emin has held so long may not be allowed to relapse into barbarism.

$$
\text { J. S. K. }
$$

\section{A NEW PERMIAN RHYVCHOCEPHALIAN REP / ILE.}

A MONG the many publications which have recently startled the paliontological world, one of the most important is unquestionably Dr. Hermann Credner's description of Palcohatteria, a new Permian Rhynchocephalian from the Plauen beds near Dresden-beds which have supplied the same author with copious material of Stegocephalians, both in the perfect and larval stages, the subject of his well-known admirable monographs. Great interest attaches to the present discovery from a purely zoological point of view, owing to the close relationship of this, one of the earliest of Reptiles, to the existing New Zealand Sphenodon (or Hatteria), the anatomy of which was first made known some twenty years ago by Dr. Guinther in his classical paper in the Philosophical Trans-

${ }^{\text {I }}$ H. Credner, "Die Stegocephalen und Saurier aus dem Rothl egenden des Plauenschen Grundes bei Dresden," vii. Theil. Palaohatteria longi-
caudata (\%itschr. Dentsch. Geol. Ges., r888, pp. 437-557, Pl. xxiv.-xxvi.). 